University of Nebraska - Lincoln

DigitalCommons@University of Nebraska - Lincoln

Faculty Publications, Department of Child, Youth, and Family Studies

$9-2019$

\title{
Going beyond defining: Preschool educators' use of knowledge in their pedagogical reasoning about vocabulary instruction
}

Julie Dwyer

Rachel E. Schachter

Follow this and additional works at: https://digitalcommons.unl.edu/famconfacpub

Part of the Developmental Psychology Commons, Family, Life Course, and Society Commons, Other Psychology Commons, and the Other Sociology Commons

This Article is brought to you for free and open access by the Child, Youth, and Family Studies, Department of at DigitalCommons@University of Nebraska - Lincoln. It has been accepted for inclusion in Faculty Publications, Department of Child, Youth, and Family Studies by an authorized administrator of DigitalCommons@University of Nebraska - Lincoln. 


\title{
Going beyond defining: Preschool educators' use of knowledge in their pedagogical reasoning about vocabulary instruction
}

\author{
Julie Dwyer ${ }^{1} \&$ Rachel E. Schachter ${ }^{2}$ \\ 1 School of Education, Quinnipiac University, Hamden, Connecticut \\ 2 Department of Child, Youth and Family Studies, College of Education and \\ Human Science, University of Nebraska-Lincoln, Lincoln, Nebraska \\ Corresponding author - Julie Dwyer PhD, Quinnipiac University, School of Education, \\ 370 Bassett Road, North Haven CT. Email: jdwyer@qu.edu \\ ORCID \\ Julie Dwyer https://orcid.org/0000-0002-7872-8849 \\ Rachel E. Schachter https://orcid.org/0000-0003-3951-858X
}

\begin{abstract}
Previous research investigating both the knowledge of early childhood educators and the support for vocabulary development present in early childhood settings has indicated that both educator knowledge and enacted practice are less than optimal, which has grave implications for children's early vocabulary learning and later reading achievement. Further, the nature of the relationship between educators' knowledge and practice is unclear, making it difficult to discern the best path towards improved knowledge, practice, and children's vocabulary outcomes. The purpose of the present study was to add to the existing literature by using stimulated recall interviews and a grounded approach to examine how 10 preschool educators used their knowledge to
\end{abstract}

Published in Dyslexia. 2019; pp 1-27. DOI: 10.1002/dys.1637

Copyright (C) 2019 John Wiley \& Sons, Ltd. Used by permission.

Submitted 16 September 2018; revised 15 May 2019; accepted 2 September 2019 
made decisions about their moment-to-moment instruction in support of children's vocabulary development. Results indicate that educators were thinking in highly context-specific ways about their goals and strategies for supporting vocabulary learning, taking into account important knowledge of their instructional history with children and of the children themselves to inform their decision making in the moment. In addition, they reported thinking about research-based goals and strategies for supporting vocabulary learning that went beyond simply defining words for children. Implications for research and professional development are discussed.

Keywords: language, teaching, vocabulary

\section{INTRODUCTION AND LITERATURE REVIEW}

There is general consensus regarding the critical role that vocabulary knowledge plays in children's long-term academic success (E. Hoff, 2013; National Early Literacy Panel, 2008; National Reading Panel, 2000; Snow, Burns, \& Griffin, 1998). Specifically, we know that early vocabulary knowledge is a strong predictor of later reading comprehension (Beck \& McKeown, 2007; Cunningham \& Stanovich, 1997; M. Senechal, Ouelette, \& Rodney, 2006; Quinn, Wagner, Petscher, \& Lopez, 2015). Yet we know that there are substantial differences in vocabulary size between children beginning as early as 18 months of age (Fernald, Marchman, \& Weisleder, 2013) and that these early differences tend to widen overtime (E. Hoff, 2006; J. Huttenlocher, Waterfall, Vasilyeva, Vevea, \& Hedges, 2010).

In order to address these large and early gaps, it is incumbent on early childhood educators to provide early childhood experiences that develop children's vocabulary in order to support later reading achievement and school success. Indeed, there is evidence that educators working in early childhood settings have the potential to support and increase children's vocabulary development (e.g., Biemiller \& Boote, 2006; Cabell, Justice, McGinty, DeCoster, \& Forston, 2015; Marulis \& Neuman, 2010; Mol, Bus, \& De Jong, 2009; National Early Literacy Panel, 2008; Weiland \& Yoshikawa, 2013). Given the promise of early childhood education for supporting children's vocabulary development, many researchers have turned to understanding these contexts in order to improve children's outcomes. One important finding from this work is that early childhood settings are providing less than optimal support for vocabulary development (Dwyer \& Harbaugh, 2018; Pelatti, Piasta, Justice, \& O'Connell, 2014; Wright \& Neuman, 2014). 
To address this issue, researchers have tried to understand educatorlevel characteristics and practices that contribute to children's vocabulary acquisition, focusing on what early childhood educators know about supporting vocabulary development and what they $d o$ in their enacted practice. However, missing from this body of literature is investigation into a critical linking step-how educators are taking what they know and using it to make decisions that result in enacted practice. This process that Shulman (1987) has termed pedagogical reasoning, is essential in the act of teaching; yet to date, it has been infrequently studied in the context of early childhood educators' vocabulary instruction. Thus, this paper seeks to address this gap by investigating early childhood educators' pedagogical reasoning about supporting vocabulary during practice. By understanding this process, we can learn more about current practices such that they can be enhanced to improve vocabulary instruction and impact long-term reading outcomes.

\subsection{Literature review}

To understand how to best improve vocabulary instruction in early childhood education, researchers have tried to measure what educators visibly do to support vocabulary in their language interactions with children, what educators know about teaching vocabulary, and how both of these are associated with child vocabulary outcomes. From these, we have learned a great deal about vocabulary instruction in early childhood settings. However, there are several limitations to these approaches that prevent a more nuanced understanding of vocabulary instruction.

\subsubsection{Measuring vocabulary instruction}

A wide variety of contexts, instructional moves, and educator behaviors have been shown to support children's vocabulary development. Some of these strategies include labelling (Pan, Rowe, Singer, \& Snow, 2005), use of gestures (B.A. Wasik, Bond, \& Hindman, 2006; R. Silverman \& Crandell, 2010), hearing and using vocabulary in multiple contexts (Coyne, McCoach, Loftus, Zipoli, \& Kapp, 2009; Stahl \& Fairbanks, 1986; B.A. Wasik et al., 2006), asking children to produce the phonological representation of a word (Beck \& McKeown, 2007; Biemiller \& Boote, 2006; Rosenthal \& Ehri, 2008; M. Senechal, 1997; M. Senechal, Thomas, \& Monker, 1995), and defining words for children (B.A. Wasik, Hindman, \& Snell, 2016; Beck \& McKeown, 2007; Brett, Rothlein, \& Hurley, 1996; 
Elley, 1989; Hadley, Dickinson, Hirsh-Pasek, Golinkoff, \& Nesbitt, 2016; Penno, Wilkinson, \& Moore, 2002; Pressley, Disney, \& Anderson, 2007; R. Silverman \& Crandell, 2010).

Although there are many instructional strategies that have been empirically shown to foster vocabulary development, researchers seeking to study or measure vocabulary instruction have generally focused on one instructional move from the list above-explicit provision of word meanings or definitions (e.g., Landry, Swank, Anthony, \& Assel, 2011; Pelatti et al., 2014; Wright \& Neuman, 2014). This may be in part due to a body of research suggesting that providing children with explicit definitions of words (most often studied in the context of interactive read alouds) has demonstrable effects on children's vocabulary knowledge (e.g., Collins, 2010; B.A. Wasik et al., 2016; Gonzalez et al., 2010). This focus may also result from findings suggesting that explicit instruction is necessary in order to influence children's vocabulary outcomes (e.g., S.B. Piasta, Connor, Fishman, \& Morrison, 2009) or possibly from the challenges inherent in operationalizing other types of vocabulary instructional strategies for reliable documentation (Kane \& Staiger, 2012). Thus, what has been measured or observed about how early childhood educators are supporting vocabulary development tends to be relatively narrowly focused on definitions. This may be partially contributing to the research findings that the observed quantity and quality of vocabulary instruction in preschool classrooms are less than optimal (Landry et al., 2011; Pelatti et al., 2014; Wright \& Neuman, 2014). Thus, more efforts are needed to understand the enactment of other instructional strategies for supporting vocabulary.

\subsubsection{Measuring knowledge}

In addition to examining the quantity and quality of support for vocabulary occurring in early childhood classrooms, researchers have endeavored to understand preschool educators' knowledge about supporting vocabulary development. Traditionally, knowledge about supporting language development has been measured through static measures that assess a variety of types of knowledge for teaching (Shulman, 1987), often focusing on what Hindman and Wasik (2011) call "conceptual and procedural knowledge" (p. 353; e.g., Hindman \& Wasik, 2011; Neuman \& Cunningham, 2009; O’Leary, Cockburn, Powell, \& Diamond, 2010; Piasta et al., 2017). These measures generally seek to understand educators' 
broader knowledge about supporting language and literacy in early childhood settings, with embedded items specific to vocabulary. Across studies that have employed such measures, early childhood educators tend to accurately answer $60-70 \%$ of items (see Cash, Cabell, Hamre, DeCoster, \& Pianta, 2015; Piasta et al., 2017).

The connection between measures of knowledge and children's outcomes is not conclusive. Some researchers have demonstrated associations between educators' knowledge and their enacted language and literacy practices (e.g., Hindman \& Wasik, 2011; Schachter, Spear, Piasta, Justice, \& Logan, 2016; Spear et al., 2018), whereas other studies have found no or minimal associations (e.g., Carlisle, Correnti, Phelps, \& Zeng, 2009; Pianta et al., 2014). In addition, studies have shown variable associations between educators' knowledge and children's outcomes, in that knowledge only seems to predict a subset of child-level skills (Cash et al., 2015; S.B. Piasta et al., 2009). Perhaps more importantly, when researchers have attempted to shift educators' knowledge as a mechanism for improving children's outcomes via improved practice, there have been limited or minimal effects on children's language and literacy outcomes (see Markussen-Brown et al., 2017 for a comprehensive review). Thus, the extant body of literature does not provide the field with a clear or definitive understanding of the relationship between educators' knowledge, their enacted practice, and children's vocabulary outcomes.

Despite this puzzling set of findings, there are strong theoretical reasons to believe that educators' knowledge plays a key role in their enacted practice and on children's outcomes (B.A. Wasik \& Hindman, 2011; Grossman, 1990; Shulman, 1987). One possible explanation for the difficulty in empirically demonstrating these hypothesized links may lie in the way the field has traditionally measured knowledge. Most researchers depend on traditional paper and pencil measures to assess teachers' knowledge about how children learn language skills (e.g., Cash et al., 2015; Hindman \& Wasik, 2011; S.B. Piasta et al., 2017), which are created from researchers' perspectives but do not take into account the other types of knowledge that are important in the work of teaching (Piasta et al., 2017; Shulman, 1987). Furthermore, they are removed from the immediate context in which educators work and use knowledge to make decisions about practice (Cohen, Raudenbush, \& Ball, 2003; Lampert, 2001). Indeed, some researchers have suggested that the type of knowledge that can be accessed via static measures may not be the same 
as the knowledge that educators are using when enacting instruction (Carlisle et al., 2009; Schachter, 2017).

\subsubsection{Knowledge in use}

To address the issues raised above, this study investigates a critical step in the pathway between educators' knowledge and practice-how educators use their knowledge, both what is typically measured and other forms of knowledge educators may be using, in the moment, to make decisions about supporting word learning. We argue that by examining educators' thinking, conceptualized here as pedagogical reasoning (Shulman, 1987), during language interactions with children, we may better understand the relationship between the knowledge that they hold and what they do in the classroom. One procedure for understanding educators' knowledge in use is the stimulated recall interview procedure. In this procedure, educators are shown recordings of their instruction that serve as stimuli for facilitating recall of their in-the-moment thinking (cognitive processes) during instruction (Clark \& Yinger, 1977; Shavelson \& Stern, 1981). Using this procedure provides insight into the nuanced way that educators use knowledge in the moment, expanding beyond what can be measured on a paper-and-pencil survey and including additional types of information that are of importance to educators.

Although it has been a long-standing procedure in K-12 research (Shavelson \& Stern, 1981), the use of stimulated recall interviews (SRIs) is a relatively new procedure in early childhood research (e.g., Cherrington \& Loveridge, 2014; Dwyer \& Harbaugh, 2018; Piasta et al., 2017; Schachter, 2017). The few studies using the stimulated recall interview procedure with early childhood educators have found that educators often use different language/terminology than researchers to describe the same observed practices (Dwyer \& Harbaugh, 2018) and have demonstrated that educators often have differing priorities than researchers' (Schachter, 2017).

To our knowledge, no research has used this method to investigate preschool educators' knowledge in use when providing support for vocabulary development. By focusing on educators' pedagogical reasoning during practice in this study, we are able to reveal how educators operationalize vocabulary support or word learning-which may or may not be the same as researchers. Findings regarding educators' knowledge in use and the ways they describe their support for vocabulary have the 
potential to be an important starting point for educational researchers and professional development providers seeking to improve both educators' knowledge about and practice related to supporting the development of children's vocabulary knowledge-important foundations for children's subsequent reading achievement.

\subsubsection{Theoretical framework}

A phenomenological orientation (J.W. Creswell \& Creswell, 2018; Marton, 1981) to studying the work of teaching was employed. This allowed us to focus on how the external (observations of teaching) were connected to the internal (pedagogical reasoning about teaching) with a specific focus on vocabulary instruction thus addressing the gap in understanding how knowledge is connected to practice. We also used Shulman's (1987) notion of pedagogical reasoning as the foundation for conceptualizing knowledge in use. He describes the work of teaching as the process of assimilating multiple types of knowledge to enact instruction. For the purposes of this study, we were interested in how educators engaged in pedagogical reasoning to bring about vocabulary instruction and the types of knowledge that they used. Although Shulman and others have identified a variety of types of knowledge used to inform instruction (e.g., content knowledge, pedagogical knowledge, pedagogical content knowledge, knowledge of learners and their characteristics, etc.), we were interested in exploring educators' perspectives on knowledge and as such were open to a variety of types of knowledge use.

\section{PRESENT STUDY}

The purpose of the present study is to add to the existing literature by examining how educators made decisions about their moment-to-moment instruction in support of children's vocabulary development. We asked: "How do preschool educators report reasoning about supporting vocabulary development during practice?" This investigation may serve as a critical starting point for researchers and professional development providers seeking to bolster preschool educators' knowledge of and practice around support for vocabulary development, with the ultimate goal of improving children's proximal and distal reading achievement. 


\section{METHOD}

\subsection{Participants}

Participants $(n=10)$ were part of a larger study of the language environment in licensed preschool settings. Educators in the larger study ( $n$ $=23$ ) were recruited through the state Quality Rating and Improvement System (a voluntary registry for early care and education settings that offers support and opportunities for professional development). In exchange for participation, educators were offered the opportunity to participate in a free professional development workshop after the research study for continuing education units. The participants for the current study were those who participated in SRIs (described subsequently) in addition to other study activities.

All were female participants, worked in licensed early education settings within 30 miles of a large northeastern city and self-identified as the lead educator in their setting. The years of experience, setting type (family day care or center-based care), area income level, age of children served, and highest level of education varied (see Table 1), whereas the sample was homogenous in self-reported race/ethnicity. Educators were assigned pseudonyms consistent with their cultural backgrounds.

Table 1. Educator demographic characteristics

\begin{tabular}{|c|c|c|c|c|c|c|}
\hline $\begin{array}{l}\text { Educators } \\
(N=10)\end{array}$ & $\begin{array}{l}\text { Self-identified } \\
\text { race/ } \\
\text { ethnicity }\end{array}$ & $\begin{array}{l}\text { Years of } \\
\text { experience }\end{array}$ & $\begin{array}{l}\text { Education } \\
\text { level }\end{array}$ & $\begin{array}{l}\text { Setting } \\
\text { type (home } \\
\text { or center } \\
\text { based) }\end{array}$ & $\begin{array}{l}\text { Median } \\
\text { household } \\
\text { income } \\
\text { level of } \\
\text { community }\end{array}$ & $\begin{array}{l}\text { Age range } \\
\text { of children } \\
\text { in setting }\end{array}$ \\
\hline Bridget & Caucasian & $11-15$ years & Some college & Home & $\$ 111,714$ & 3 months -5 years \\
\hline Danielle & Caucasian & $\geq 21$ years & Master's & Home & $\$ 42,270$ & 3 months -5 years \\
\hline Deborah & Caucasian & $\geq 21$ years & Master's & Center & $\$ 133,179$ & $3-5$ years \\
\hline Donna & Caucasian & $\geq 21$ years & Bachelor's & Center & $\$ 70,591$ & $3-5$ years \\
\hline Erin & Caucasian & NA & NA & Home & $\$ 47,155$ & 3 months -5 years \\
\hline Jesse & Caucasian & $\geq 21$ years & Bachelor's & Center & $\$ 105,889$ & $4-5$ years \\
\hline Judy & Caucasian & $\geq 21$ years & Master's & Center & $\$ 116,612$ & $3-5$ years \\
\hline Leah & Caucasian & $\geq 21$ years & Associate's & Center & $\$ 92,685$ & $3-5$ years \\
\hline Lisa & Caucasian & $11-15$ years & Master's & Home & $\$ 131,535$ & 3 months -5 years \\
\hline Luisa & Latina & 4-10 years & Bachelor's & Center & $\$ 70,591$ & $3-5$ years \\
\hline
\end{tabular}

* Donna and Luisa worked in the same setting (different classrooms).

** Standards for classifying income levels were based on the median household income level of the city/town in which the setting was located. Settings classified as "low" income had a median household income level of less than $\$ 60,000$. Setting classified as "high" income had a median income of greater than $\$ 80,000$. 


\subsection{Measures}

\subsubsection{Background questionnaire}

Educators completed a background questionnaire that included questions about their gender, age, race/ethnicity, highest level of education, language background, years of experience working in early childhood settings, and ages of the children with whom they worked.

\subsubsection{Stimulated recall interview}

Two observations were conducted in each setting, with a mean of 49 days between observations (SD = 29 days). Two observations were conducted not to investigate change over time but rather to garner additional data to reveal patterns in educators' pedagogical reasoning. We do not have any reason to believe that there were any systematic changes between the first and second observation.

\section{Overview}

During the observations, the researchers (the first author and an early childhood education doctoral student) videotaped 1 to $2 \mathrm{hr}$ of interactions between the educator and children in the setting and took field notes. Each observation was then followed by an SRI wherein the participant and the researcher co-viewed the videos of instruction, which served as a stimulus for recalling in-the-moment thinking, pedagogical reasoning, about practice without interrupting the act of teaching (Clark \& Yinger, 1977; Shavelson \& Stern, 1981). This procedure resulted in 19 SRIs (one educator only completed one SRI).

\section{Selection of stimuli}

Selecting clips to serve as the stimuli for the SRI was a multi-step process. First, during the observation and recording, a researcher took field notes on the domain of interest in the larger study: provision of support for language development. For the larger study, we focused on interactions in which the educator engaged in behaviors or moves that elicited language from her students (e.g., responding contingently to a child's utterance, asking an open-ended question, etc.), modelled the use of language for students (e.g., by extending children's utterances, using sophisticated vocabulary, etc.), and/or provided support for learning individual vocabulary words (e.g., labelling, providing information about word meaning, 
etc.). Thus, including support for vocabulary development was a subdomain of interest in the broader study.

When the observation and field notes were completed, the entire recording of practice was uploaded to a laptop computer. Because the researcher could not conduct and SRI on the entire 90-120-min video, field notes on the domain and subdomains of interest were used to select a 20-min video segment of small-group activities in which the educator provided the most dense support for language development to view during the SRI. Next, field notes were again consulted, this time to use criterion-based sampling to identify four to six specific language interactions with children within the selected 20-min clip, or "instances," that would be stopping points to use as stimuli during the SRI. The criteria used to identify these stopping points corresponded to the subdomains of interest described previously.

\section{SRI procedure}

Following the selection of stimuli, the educator and the researcher co-viewed the entire 20-min video segment. The video was stopped at each of the four to six researcher-identified instances, at which point the researcher used one or more of a series of open-ended questions or prompts designed to elicit information about the educator's in-the-moment decision making, including: "What were you thinking about there?"; "Tell me about why you said that"; or "Tell me about your thought process here." In addition to the criterion-based sampling that focused on the researchers domains of interest, we also used participant-initiated sampling (Schachter \& Freeman, 2015), wherein we encouraged educators to stop the video any time during the viewing of the 20-min video segment to comment on moments of practice that were important to them.

To preserve memory of internal cognition (Lyle, 2003), the researcher and the educator co-viewed the 20-min segment together as soon as possible after the observation. For 18 of the 19 interviews, the SRI was conducted the same day as the video observation, generally within an hour of the observation. One interview was conducted the following day due to technological difficulties, but within the timeframe recommended by Schachter and Freeman (2015). A total of $380 \mathrm{~min}$ (6.33 hr) of practice were co-viewed with educators across the sample. 
Initial data preparation

Each SRI was video recorded and the interviews were transcribed by a professional transcription service. Once an interview was transcribed, the researcher that conducted both the SRIs used the observation video to add descriptions of the enacted practice preceding the point at which the educator or researcher stopped the video during the SRI, also referred to as first-order data (Marton, 1981). For example, immediately preceding the transcript of the educator's pedagogical reasoning about a researcher-selected clip, the researcher added the following first-order data to provide context: "The educator is sitting on the ground playing with the children. The children are writing with crayons and markers. One of the very young children is making an 'Eeh, eeh' noise when trying to open a marker and the educator leans over and says to the child 'You need help? Help me' as she helps the child with what she wanted." Immediately following that first-order data is the transcribed SRI interaction between the educator and the researcher:

o Researcher: "Okay, so-so tell me what you were thinking."

o Educator: "Um, so help, help me is a real common um, word or phrase I try to teach the kids because they often need help. And instead of whining or fussing it's a way for them to get their needs met. Um, and I can kinda tell she wanted help by she was signaling to me. So I try to model the words so then next time she might be able to say help."

There were a total of 166 instances of first-order and interview (second order) data of educators' pedagogical reasoning.

\subsection{Analysis}

\subsubsection{Further data preparation}

Data for this study were culled from the larger corpus of SRI data to address our present research question regarding educators' pedagogical reasoning about teaching words. To identify instances where the educator talked about supporting vocabulary development, both authors read through all 166 instances of pedagogical reasoning to identify potential instances where educators were explicitly describing supporting vocabulary or word learning. Specifically, we selected instances in which 
the educator explicitly talked about her thought process related to children's word learning. All instances were double coded for inclusion, with disagreements settled through discussion between the authors. In total, 54 instances of an educator describing support for vocabulary learning were found. These constitute the current dataset.

\subsubsection{Data analysis}

We used a grounded approach to explore the data and develop an emerging theory regarding educators' pedagogical reasoning about supporting vocabulary development (Corbin, Strauss, \& Strauss, 2014), with each researcher/author reviewing the data independently to develop preliminary theories then meeting together to discuss initial findings. Importantly, we used a phenomenological approach (Marton, 1981) we did not use a priori theories or ideas about supporting children's vocabulary learning or knowledge types. Rather, we focused specifically on educators' reports of their pedagogical reasoning about teaching words/ vocabulary. During these analyses, the descriptions of the instruction preceding educators' pedagogical reasoning, or first-order data, were used to provide context and describe the phenomenon for which the participants provided their perspective during the SRI. For the sake of brevity, the first-order data are not always reported verbatim in the results, but we used these data to provide the context necessary to understand educators' pedagogical reasoning. After discussing the emerging theory, we returned to the data to confirm, disconfirm, and elaborate patterns related to our theory (J.W. Creswell, 2007).

In generating our theory, we found that educators were considering two main ideas in their pedagogical reasoning about teaching words/ vocabulary. These were reasoning about words to teach and strategies for teaching words to young children. As part of this pedagogical reasoning, several sources or types of knowledge were used by educators. Specifically, we found that educators used knowledge of the curricular context, knowledge of the individual children in their classroom, and knowledge of general word-related needs (see Tables 2 \& 3 for definitions and examples). In their reasoning about instructional strategies, educators used knowledge of instructional strategies for teaching young children. As our purpose was to describe the breadth of educators' pedagogical reasoning, we did not code for frequency of the occurrence of these ideas across participant; however, we do note which subcodes were rarer in educators' reports. 
Table 2. Educators' reported purposes and knowledge used for selection of vocabulary

\begin{tabular}{lc} 
Reported purpose & Definition \\
\hline Selecting words based on knowledge of the curricular context \\
$\begin{array}{l}\text { Knowledge of } \\
\text { previously taught } \\
\text { words-reviewing }\end{array}$ & $\begin{array}{l}\text { Educator reports selecting words to } \\
\text { review child/children's knowledge } \\
\text { of words based on her knowledge } \\
\text { of words that have been previously } \\
\text { taught or words that are related to an } \\
\text { upcoming topic }\end{array}$
\end{tabular}

Knowledge of previously taught words—assessing

Educator reports selecting words to assess child/children's knowledge of words based on her knowledge

Example of educators' pedagogical reasoning and the preceding context

Context: The educator has taken a video of baby birds that are in a nest that is right outside of their classroom and is talking to them about how you can see the babies breathing. The says "Remember when we did the stethoscopes? What were we listening for?" A child said "Our heart." And she said "Yeah, what made your heart beat faster?" A child said "The stethoscope" and the educator says "What made your heart beat faster? Remember when we ran? When we ran down there and ran back? When we were breathing faster, our heartbeat was going faster. The birds are breathing, watch. See, they are taking breaths (mimics breathing)." A child says "Can I do it?" and she says "Yeah, take a breath. Your belly. Yeah, see what happens? What happens to Timmy's belly when he is breathing?"

Deborah: "..You know, just to bring back home again the things that we talk about one week just does not get in a basket and tucked away. We bring it back out and make it relevant to whatever we have that's coming." of words that have been previously taught or words that are related to an upcoming topic
Context: The educator was sitting on the floor reading a book about dinosaurs to children. She read a page that said "Velociraptor's name means 'speedy thief.'” She then said "Speedy is another word for fast and thief is someone who steals things. What is he stealing here?" A child said "Eggs" and she continued reading a page that said "This dinosaur also stole eggs from other dinosaurs to eat." A child said "We learned about that" and she said "We did, that's why his name was egg catcher."

Judy: "...And that showed up in a couple of different books (last week). Um, and then defining just different areas in that, what it means to be a herd, and-speedy. Fast. Thief, someone who steals something. And then, um, building comprehension by asking, "What do-what does he steal?' to make sure that ... to see ... that was just a check-in. It was more for him, for Andrew too, because of the ELL."

\section{Selecting words based on knowledge of specific children}

Knowledge of words children in the setting are unlikely to know
Educator reports selecting words based on them likely being unknown to children
Context: The educator is eating breakfast with the children and passing out croissants. She asks, "What are these?" A child responds, "Breads" and she replies, "They're French breads called croissants."

Donna: "I think that's important that they are labeling their food. Cause, I mean, it might be unfamiliar to some children. You know? And they are. They're a croissant, and a croissant is a French bread, so that might not be something that they eat a lot of, so at least it's giving them the vocabulary words." 
Table 2. Educators' reported purposes and knowledge used for selection of vocabulary (continued)

\begin{tabular}{ll} 
Reported purpose & Definition \\
\hline $\begin{array}{c}\text { Knowledge of background } \\
\text { and age of different } \\
\text { children in the setting }\end{array}$ & $\begin{array}{c}\text { Educator reports selecting words based } \\
\text { on the different background and age of } \\
\text { children in her setting }\end{array}$
\end{tabular}

Knowledge of specific child characteristics of children in the setting that are related to vocabulary learning

Educator reports selecting words based

Example of educators' pedagogical reasoning and the preceding context

Context: The educator is doing puzzles with several children on the floor. She is talking with children about the different puzzle pieces (monkey, seal, rhinoceros). One child labels a puzzle piece "A monkey" and the other child says "Some people call them gorillas." The educator proceeds to talk about the difference between monkeys and gorillas.

Lisa: “Um, I knew that she, Paula, probably had a broader, um, vocabulary and I needed to continue to engage her. When she said monkey, I knew she was capable of defining orangutan, probably gorilla, and something broader than that ... Um, but it was interesting that when Sera engaged in that same direct activity, I turned it one way and Paula identified all three [seal, monkey, rhinoceros] successfully. Turned it the other way and Sera had a lotta diffi-uh, more difficulty." on specific child characteristics related to vocabulary learning, including English language proficiency, children's native language background, children's vocabulary size, and past language issues
Context: The educator is sitting on the rug reading a book to two children and she reads "Lilly is a bison, a baby bison, and they are called calves." She says "So it's just like a cow, it's a calf."

Leah: “Maria, who's the other one on my left. She's-calf meant nothing to her, I'm sure .... She's just like out there-like she's not ready to sit and hear and learn yet. She's just not there. Uh, she's only been in the country for a few months."

\section{Selecting words based on knowledge of general language needs}

Knowledge of what words that would be high utility and transferrable across contexts
Educator reports selecting words that would be useful and applicable outside of the early childhood setting
Context: The educator is serving children lunch. She is moving around the kitchen getting them different lunch items. Three of the children are at a small table and there is one baby sitting in a high chair. The baby says "Eh!" The educator says "Eh! How about instead of that you say, 'More?"'

Danielle: “I feel as if I make the mistake when I go 'Eh' after she does it, because, you know, mimicking it, or copying it is just gonna reinforce her to do it again. But then, I kind of corrected myself right away and said, 'Hey, let us do 'more' instead.' 'Mmmm.' When she whines, it is a 'Mmmm."'

*All names have been changed. 
Table 3. Educators' reported use of instructional strategies for supporting vocabulary development

\begin{tabular}{ll} 
Reported strategy & Definition \\
\hline General pedagogical strategies & \\
$\begin{array}{ll}\text { Providing support for } & \text { Educator reports supporting } \\
\text { vocabulary that is } & \text { vocabulary development } \\
\text { contingent to children's } & \text { within the context of children's } \\
\text { immediate language, } & \text { immediate comments or focus of } \\
\text { interests, and activities } & \text { interest }\end{array}$
\end{tabular}
Example of educators' pedagogical reasoning and the preceding context

Context: The educator is playing on the floor with children with various toys. One girl is playing with eggs that break into half that can be put back together by matching the colors and the shapes on the inside of the eggs. The educator works with the child to match the halves of the eggs. She holds up one half of an egg and says "Which one goes with this one? Can you find a match?" The girl says "It's really hard. The educator says "Look in those pieces. Which one goes with this one?" as she spreads out the various egg halves. The girl holds up the matching egg with a blue triangle inside. The educator says "Blue what?" The child says "Blue!" The educator says "What shape?" and the girl says "It's triangle!" The educator says "Blue triangle! Yay! You did it!"

Bridget: "Anything I can find and grab that I can see that they are playing with that will teach them something. I definitely focus more on opportunistically than pulling stuff out, and um, I find that they actuallythey respond better versus if I pull something out and force them to-okay, you are gonna learn this nowIt does not seem to work, uh, cuz they-they are so young, and they just-you know, they-their minds are constantly going, going, going, going, going, so whenever I can see that opportunity, I snag it, and it really does not interrupt her play, and she does not really know that she's learning, but yet she's learning something along the way."

\section{Vocabulary instructional strategies}

Modelling

Educator reports teaching vocabulary by showing child/ children how to use words in context
Context: The educator is sitting on the floor playing with blocks with some of the children. One of the toddlers went over to begin playing in the pretend kitchen. The child is trying to open the play refrigerator and is having trouble and says "Eeh." The educator says "Are you going to cook some food Leah*?" and the child says "Ye." The educator says "Yes? You need this open?" and opens the refrigerator for the child.

Erin: "Um, so it—back to kind of like when um, I was kind of anticipating what she wanted and giving her the words. Um, like when I asked her if she wanted to open it and she shook her head yes. I said, "Oh, you said yes." 
Table 3. Educators' reported use of instructional strategies for supporting vocabulary development (cont.)

\begin{tabular}{|c|c|c|}
\hline Reported strategy & Definition & $\begin{array}{l}\text { Example of educators' pedagogical reasoning and the } \\
\text { preceding context }\end{array}$ \\
\hline Exposure & $\begin{array}{l}\text { Educator reports supporting vocabulary } \\
\text { learning through exposing child/ } \\
\text { children to words }\end{array}$ & $\begin{array}{l}\text { Context: The educator is interacting with two children as } \\
\text { they play with blocks. One child says "It does not explode." } \\
\text { "Oh volcanoes? Oh, they erupt, right, he said we were } \\
\text { going to make one but we have not made one, they erupt, } \\
\text { they (gestures exploding) and all the lava comes out." } \\
\text { Leah: "I'm just using different words. Unfamiliar words. Just } \\
\text { giving them different language, different words." }\end{array}$ \\
\hline Labelling & $\begin{array}{l}\text { Educator reports teaching vocabulary by } \\
\text { labelling objects or concepts for child/ } \\
\text { children }\end{array}$ & $\begin{array}{l}\text { Context: The educator is sitting on the floor playing with } \\
\text { children. One child has built a three-legged structure } \\
\text { out of magnet blocks. The educator says, "Nice tripod! } \\
\text { Well, it's a quadripod, cause it has four legs. See her } \\
\text { [the researcher's] camera sits on a tripod? It has three } \\
\text { legs. Yours has four legs, so it's a quadripod." The child } \\
\text { removes one of the legs and the educator says, "Now it's } \\
\text { a tripod." } \\
\text { Danielle: "I'm trying not to, you know, discourage what he's } \\
\text { doing. But, um, to also give it a name-but, in order for } \\
\text { him to know what a quadrupod is, I had to show him a } \\
\text { typical thing is a tripod." }\end{array}$ \\
\hline $\begin{array}{l}\text { Asking children to say the } \\
\quad \text { word }\end{array}$ & $\begin{array}{l}\text { Educator reports teaching vocabulary by } \\
\text { having child/children produce a word }\end{array}$ & $\begin{array}{l}\text { Context: The educator is sitting on the rug and reading to } \\
\text { two children and says "He0s called a Wed-Red-Wed-a } \\
\text { Red-winged Blackbird. That's hard to say. Can you say } \\
\text { 'red-winged'?" The child says "Red-winged" and the } \\
\text { educator says "Better than I did, Red-winged Blackbird." } \\
\text { Leah: "I just wanted to hear, like I was thinking, is it me or } \\
\text { could somebody else say it [Red-winged Blackbird] right? } \\
\text { I just wanted to hear if she could get the red-winged out. } \\
\text { Like, and I know ... it's-it's a hard thing to say. And just } \\
\text { because it was a different type of bird." }\end{array}$ \\
\hline $\begin{array}{l}\text { Giving examples related to } \\
\text { children's lives }\end{array}$ & $\begin{array}{l}\text { Educator reports teaching vocabulary } \\
\text { through making connections and giving } \\
\text { examples from child/children's lives. }\end{array}$ & $\begin{array}{l}\text { Context: The educator is talking with a few children and } \\
\text { calls over to another child, saying "Serena, I was going } \\
\text { to share with Petra and Sera, we are talking a lot about } \\
\text { animals. You have Uncle Rich. Where does Uncle Rich } \\
\text { work? What does Uncle Rich do? He works at the ...?" } \\
\text { The child says "Park." The educator says "At the park? He } \\
\text { works at a zzzz ...” The children say "Zoo!" at the same } \\
\text { time as the educator says “Zoo!” The educator says “Uncle } \\
\text { Rich works with animals, he is a zookeeper!” } \\
\text { Lisa: "Again, it was just that Serena had been in and out } \\
\text { of the room. Um, even though she wasn't present at } \\
\text { the moment, I also knew that she had been in and out } \\
\text { recently enough to know that we had been really talking } \\
\text { about animals and then to tie into her piece to see if she } \\
\text { could share more information. Is that her-her uncle is } \\
\text { a zookeeper. And, um, you know, it's again sharing that } \\
\text { relatedness about [my] knowing that [she has an] Uncle } \\
\text { Rick." }\end{array}$ \\
\hline
\end{tabular}


Table 3. Educators' reported use of instructional strategies for supporting vocabulary development (cont.)

\begin{tabular}{ll} 
Reported strategy & Definition \\
\hline $\begin{array}{l}\text { Providing information } \\
\text { about word meaning }\end{array}$ & $\begin{array}{l}\text { Educator reports teaching vocabulary } \\
\text { by providing information or } \\
\text { language connected to the word } \\
\text { for child/children-separate from } \\
\text { providing the definition }\end{array}$
\end{tabular}

Defining
Example of educators' pedagogical reasoning and the preceding context

Context: The educator is doing puzzles with several children on the floor. She is talking with children about the different puzzle pieces. The children are naming the different animals. One child says "And a monkey" and the other child says "Some people call them gorillas." The educator says "Um, you are right. You're right. The thing is, this one to me looks like a monkey. I do not know what it is, but this creature, this animal, has a very long tail and likes to climb trees. When I think of gorillas, they are massive. They are two times the size of your daddy. They are double Mike's! Double daddies! At least double daddies. And monkeys can be still tiny, and they climb probably faster. Gorillas can still climb, but gorillas are massive. They are gigantic.

Lisa: "And I knew that for that puzzle we could take a vocabulary moment and expand upon just the word monkey so that she was hearing something different."

Context: The educator was sitting on the floor reading a book about dinosaurs to children and read a page that said "Scientists think that these dinosaurs traveled in groups." She then said "Do you remember from our other book what we called it, well a book we read last week, when dinosaurs traveled in groups? They were like elephants. They traveled in h-h ... .herds. Do you remember that from last week? The travel in herds. That's a group. So it would be all velociraptors."

Judy: "Oh, and that was a big, um, making a connection to last week. We were talking about herds, um, and I related to elephants, modern-day animals, that travel in groups of all the same kind of animal. Um, also for Carlos because he wasn't here last week. And that showed up in a couple of different books. Um, and then defining just different areas in that, what it means to be a herd." 


\section{RESULTS}

Educators' pedagogical reasoning about teaching words/vocabulary was complex, including multiple sources of knowledge to inform their vocabulary instruction. As described previously, these centered around selecting words and instructional strategies. During analyses, we observed that these two ideas were often connected in educators' pedagogical reasoning; specifically, the instructional strategies often seemed to be connected to educators' purposes/goals for teaching words. However, these each were informed by unique sources of knowledge that contributed to educators reasoning and educators did not always include both in their reasoning. As such, in the next sections, we describe each of these strains, as well as the individual types of knowledge that supported them. In the instructional strategies section, we address the interconnectedness of word selection and instructional strategies for educators.

\subsection{Purposes/Goals}

When reporting their in-the-moment thinking specific to supporting vocabulary development, educators often discussed how they selected words to target-or their purpose or goals for teaching words. In picking the words they would provide support for learning around, educators used knowledge of curricular context, knowledge of specific children, and knowledge of general language needs of the children in their setting (examples are included below; see Table 2 for additional examples). Importantly, educators' complex purposes/goals for supporting vocabulary development seemed to be driven by their immediate contexts, including content of their previous or current instruction, the children in their classroom, or both.

\subsubsection{Selecting words based on knowledge of the curricular context}

One common purpose for selecting words that educators discussed was to revisit vocabulary words that had been previously addressed within the classroom. They were drawing on their knowledge of previous content, instruction, and interactions (curriculum) children had experienced to inform their current interactions focusing on reviewing or assessing children's knowledge of these words. Evident in educators' pedagogical reasoning around selecting words was how their focus on specific words connected to their specific and immediate educational 
context, either because the word/s had been previously taught or were related to new topics of investigation. In one example that exemplified selecting words for review, children in Luisa's classroom had been studying plants for the past few weeks. During a center time, children were engaged in various activities in the classroom, including play at a sensory table filled with potting soil, pots, and gardening tools, planting seeds in individual pots, and writing at a writing table. Luisa sat with one child and drew a flower and labelled the parts of the flower as she went, saying "I am going to draw a flower... I'm doing a lot of flowers... I'm making my favorite flower. Look at the roots." During the SRI, she explained her pedagogical reasoning by saying "...since this week we're talking all about like flowers and how they grow. ... [I wanted to] make sure they don't forget the-they have the roots and stuff." Thus, her goal or purpose was to review information about parts of the plant and that is how she selected words to target.

In other examples, educators specifically stated that their goal of selecting a word was to assess children's knowledge of words such as when Deborah stated, "I'm kinda paying attention to who's using words we've talked about," or Judy stated, "That was just a check-in." In these instances, educators' goals/purposes were to connect back to previously taught, context-specific words and assess children's knowledge of those words, thus drawing from their knowledge of the curricular context.

\subsubsection{Selecting words based on knowledge of specific children}

Educators also frequently reported purposes for their word selection that were based on the knowledge of specific children. Educators reported using knowledge about a particular child or group of children to inform their interactions. This included knowledge about words that were likely unknown to the children in their setting, knowledge about background and age differences between children in their setting, and knowledge about specific child characteristics germane to vocabulary learning. An example of a teacher using her knowledge of words that are likely unknown to children to select words for instruction occurred in Danielle's setting when a child was playing with a toy microphone stand. Danielle said "It's collapsible. What does that mean, collapsible? It comes apart. Or folds up." When asked about her thinking during this interaction, she said "Just trying to introduce words that maybe they don't know or have not heard before." Thus, using knowledge about words, her children were unlikely to know to inform her pedagogical reasoning. 
In a different example, Donna, a center-based preschool educator, used knowledge about background differences between children in her setting to inform her pedagogical reasoning about selecting words. During a lunchtime conversation, she was talking with children about pigs, including information about the sound that pigs make ("oink"), the name of a baby pig ("piglet"), and the information that pigs like to roll in the mud to keep cool. When explaining her pedagogical reasoning about instruction, she said

... So if you do something to like show them the pig and roll in the mud...what you are teachin' the higher level children. The lower level are learning at the same time along with the name and the sound ... Cuz they are - their age and their-emotional development, they are able to handle that. They just have not been exposed to that. Do you know what I mean? So it's not that they are not capable of knowing a piglet-they are not capable of knowing it rolls in the mud- they are. They-they are no more exposed to that then they are the name and the sound of it. You knowit's just that the older ones that already know the name and the sound, they are being exposed to something more.

Here, she is giving deep information about the word pig and providing multifaceted information that is based on her knowledge of the range of children's backgrounds and age.

Other examples of educators using knowledge about the children in their setting occurred when educators used knowledge about various child characteristics related to vocabulary development, including general English language proficiency (e.g. "They are all English learners," Luisa), children's native language background (e.g., one educator described how the child's native language did not include indefinite articles, so she purposely modelled those for the child during a play-based language interaction, Judy), children's vocabulary size (e.g., "She does not have a whole lot of language. She is just now starting to use a whole lot of her words" when describing why she was labelling a fork for the child during lunch, Donna), and past language issues (e.g., one educator, when talking about why she asked a child to say a specific vocabulary word, said "And I was kind of interested in her is because with her language, where it had been difficult and we had asked for speech for her last year," Leah). Each of these various sources of information about the 
child's language background appeared to inform their pedagogical reasoning regarding which children to target for vocabulary support and what vocabulary words to teach-their goals and purposes for teaching about words.

\subsubsection{Knowledge of language needs more generally}

Educators also reported selecting words using knowledge of what words would be useful beyond their educational context. For example, several educators described wanting to provide vocabulary learning that would be high utility and transferrable for the children - that would be useful, functional, and productive words in myriad contexts. For example, when interacting with a young child playing with toy food and holding a plastic onion, Erin reported her goal in focusing on the word onion was, "so she knows what she's playing with which will hopefully connect to real life." Other examples included one educator helping a young child learn the word "help" and another educator teach a child "more"words that they reported as those that would assist the children in getting their needs met both within and outside of the educational context. Interestingly, high-utility, transferrable vocabulary learning was discussed most frequently by family day care educators when interacting with babies or toddlers.

\subsection{Instructional strategies}

\subsubsection{General pedagogical strategies}

One very common approach educators reported using to supporting children's vocabulary development occurred in the context of a global and general pedagogical strategy often found in early childhood settings-contingent responsivity. Specifically, many educators reported providing support for vocabulary development by capitalizing on what children were talking about or doing - they were taking advantage of what children were talking about, their interests in the moment, and their immediate activities to support children's acquisition of vocabulary that was related to those utterances, interests, and activities. This often co-occurred in educators' pedagogical reasoning about instructional strategies specifically focused on vocabulary learning. For example, Judy says about a language interaction she has with a child where she repeated what the child said and added a preposition: "Um, so just I-I try to expand on what he says to build in vocabulary for him and to 
build in." Although this type of contingent responsivity is, by its very nature, extemporaneous, there was some evidence that educators were intentional in this approach. For example, Deborah talked about an exchange where she was putting sunscreen on a child and talking about body parts like muscles, elbows, and shoulders and a child shruggedat which point she focused on the meaning of the word "shrug." She said about this exchange

"We had a staff meeting last night. I had it with the preschool classroom, uh, about sort of just taking advantage of unplanned moments to talk about something that was not at all in the plan and to have a moment to sort of extend the vocabulary again in a-in a meaningful way that makes sense to them and something that they kind of have a little bit of background knowledge already about."

\subsubsection{Instructional strategies for supporting vocabulary}

In addition to reporting knowledge of general pedagogical approaches, educators reported knowledge of a variety of instructional strategies specifically for teaching about words in their pedagogical reasoning. We provide examples of each strategy below (see Table 3 for additional examples of each instructional strategy). As mentioned previously, the strategy that educators described in their thinking was often interconnected with their goals for selecting words. This idea is illustrated next in an exemplar excerpt from Erin.

o Observed instruction: A child approached her with a stethoscope and she said, "Hi Doctor. Do I need a checkup? How's my breathing?" As the child listened to her heart she says "How does my breathing sound doctor? Do I sound good? How is my heart rate?" and she breathes deeply.

o Pedagogical reasoning: "I saw he was-you know um, was with the stethoscope and coming over to me, so I kind of was labeling-like he was pretending to be a doctor. You know, they use that to check the breath and the heart. So even though he wasn't verbally telling me stuff, I was kind of reading his actions and having vocabulary to go along with it." 
Here, we see Erin's purpose for teaching the word-building on the child's interest in the moment using her knowledge of the curricular context-and thus her instructional strategy of labelling not only the object but actions and ideas that would go along with how a child might commonly encounter a stethoscope while being contingent to his play initiation and following his lead. Importantly, Erin reports an intentionality in this moment in the way in which she supported vocabulary development and this seems to be more authentic to the instructional context, labelling as a means of engaging in and extending play, then perhaps other instructional strategies. For example, it may not have made sense for Erin to interrupt the child's play initiation by stopping to provide a definition of the word stethoscope.

Next, we will describe the instructional strategies educators reported knowing and how this knowledge was connected with their pedagogical reasoning around word selection. It is important to note that there was not a clear pattern in how educators reasoned about selecting words was connected with strategies; rather, these were very context specific and thus shifted as educators understood the immediate instructional moment.

\section{Modelling}

Educators at times described how they would model the use of specific vocabulary words as an instructional strategy. For example, when talking to child who was assembling the body of a toy person with body parts, Judy said, "Oh you found a leg, was it under you?" When reporting about this interaction, she stated "Well there I modeled a-an attribute-or a preposition. That it was under." This instructional strategy was also used by the educators who chose to teach high-utility words like "help" and "more" when they modelled the use of the words in contexts where they were appropriate such that children could see the correct and successful use of the terms. For example, Erin was supporting children as they wrote with crayons and markers. One child, about 18 months old, was saying "Eeh, eeh!" while trying to open a marker. Erin said "You need help? 'Help me'" as she helps the child open the marker. When asked about this interaction, Erin said "Um, so help, help me is a real common um, word or phrase I try to teach the kids because they often need help. And instead of whining or fussing it's a way for them to get their needs met. Um, and I can kinda tell she wanted help by she 
was signaling to me. So I try to model the words so then next time she might be able to say 'help'."

\section{Exposure}

Another instructional strategy that educators reported using to support vocabulary development was exposure to rich language. For example, Deborah said, "We'll just say it and hope that they eventually catch on." Relatedly, commenting on a language interaction she had related to an ocean puzzle with her mixed-age group of an 11-month-old and several three- and four-year-olds, Lisa said "You know, even Sara was in that mix. She retreated. But even at, you know, she's 11 months of age, she's hearing things. And that exposure and that language stimulation at any level is beneficial." However, these instances were less frequent across participants.

\section{Labelling}

Educators also reported labelling items for children as an instructional strategy, such as when Donna passed croissants around to the children at breakfast. She asked the children "What are these?" One child said, "Breads," to which Donna replied, "They're French breads called croissants." In reporting her thinking during instruction, Donna said, "You know, they are aware of what they are doing and eating. I think that is important that they are labelling their food." Here again, her purpose is based on knowledge of context-in that she is building on the immediate instructional moment and her instructional strategy of labelling is connected to the nature of the interaction-a conversation as children are eating breakfast. Another example was when Leah was sitting on the floor reading a book about animals with a small group of children. She was pointing to and discussing different animals in the book with children. When she came to a picture of a duck she said "Everybody, you know this one." A child says "Duck," to which the educator responds "A duck. That's a mallard, a duck." When reporting on this interaction, Leah said "Just give them what kind of duck it was. You know, the word mallard. And we have talked about different types of duck and we have this whole big thing, because there was Canadian geese one day that came and landed at the far end of the field. And they're all going, 'Ducks! Ducks!' And we, you know, talked about those are Canadian geese. We looked them up. We showed them what a mal-duck was and 
the kind they usually see would be a mallard." As with the previous interaction, Leah's instruction was context driven - and in this case, her decision making was influenced by an in-the-moment opportunity to provide a label for something children had previous experience with.

\section{Asking children to say the word}

In addition to instructional strategies that are more receptive in nature, such as modelling and labelling, educators also reported asking children to say specific vocabulary words. Bridget talked about this in regards to reading a dinosaur book on the floor with a small group of children. After reading the sentence, "Paula Parasaurolophus has a crest upon his head," she turned to Jayden and asked, "Can you say Parasaurolophus?” When describing her thinking, Bridget stated,

Sometimes I just-I mean, when it's a tough word, I say, 'I just would like to see'-you know, 'cuz Carter's most advanced in his vocabulary. I just wanted to see if he could actually get a long word like that that's kind of mixed up, um, properly, and I was actually kinda surprised. I'm like, 'Oh, all right. Good job.' I'll do that sometimes with, um, all of them ...but I did not wanna go through everybody 'cause I know how tough that word is, and I did not want anybody else to feel bad that they could not say it. So, I just threw that out to Jayden.

Here, her implicit goal/purpose was to assess children's knowledge and understanding, and she did this by having a child produce what she deemed to be a difficult word. Bridget was also using her contextual knowledge to select a child who she believed to be capable of producing the word. It is important to note that educators appeared to use this strategy with words that they deemed difficult to pronounce rather than as an overarching strategy for supporting the learning of all vocabulary words. This was a somewhat less frequently reported strategy by educators.

Giving examples related to children's lives

Educators also supported children's word learning by giving them examples related to their life experiences. For example, when reading a book about a magical kingdom to a small group of children, Lisa read 
a sentence including the word "cavern" and she paused to ask the children "What is a cavern?" When it was clear children did not know, she said, "In the book We're Going on a Bear Hunt, the bear is in a cavern. So what's another word for a cavern? The bear was inside of the..?" When children responded, "Cave," she confirmed, "Cave, or cavern." In discussing her thinking in this moment, Lisa said, "We're Going on a Bear Hunt, that should be quite familiar with these kids. And, stepping off, if they didn't know what a cavern was, I was trying to bring in the piece that they would be familiar with." Here again, the educator's goal was to tailor instruction to children and this was achieved by building examples that she knew were familiar to children and relevant to their lives. Interestingly, here, the connection between educators' understanding of the context and instructional strategy is visible to observers as she explicitly makes the connection between the new word and children's previous experiences. However, this was not always the case in previous examples such as the opening vignette about the stethoscope.

\section{Providing information about word meaning}

Another approach that educators used was to provide information about word meanings. These provisions of additional information tended to be different from and go beyond a simple definition, as in the example presented about the stethoscope. In a different example, children in Jesse's setting were observing and interacting with a series of animal skulls and jawbones. One child held up a skull with long sharp teeth and asked the educator "Is this a carnivore?" Jesse responded by providing information about attributes of carnivores, including that they have long tusks or teeth in the front that are for ripping and explicitly stating that animals that have those teeth are carnivores. In addition, she provides information about herbivores as a comparison point-she adds that herbivores do not tend to have long sharp teeth, as they do not need to rip plants apart. Jesse sits with this child for several minutes as he examines several other skulls and she asks him several times to look at the teeth to make a guess about what type of animal it was. When asked about this interaction, she said "I just wanna give him as much information as possible about what a carn - how to distinguish a carnivore. How to distinguish a carnivore from other kinds of animals, and basically, it's through the ripping teeth that we tend to distinguish because they bite and they rip, so... Every time we discuss animals, those things come up. What do 
they eat? How do we know what that's what they eat? There's not many ways for you to tell other than the mouth and the ripping." In this example, Jesse provided information about carnivores that extended beyond the straightforward definition "Carnivores eat meat."

\section{Defining}

Educators rarely discussed defining words as a strategy for teaching children vocabulary. They more often they talked about the other strategies outlined in the previous paragraphs. There were, however, a few instances where educators reported defining words as an instructional strategy in their thinking. For example, Donna stated, "I try to put words - the definition to it, in words that they could understand."

It is important to note that there were several instances where an educator was observed defining a word for children in the first-order data, but the educator did not report defining words as her instructional strategy or in her reasoning about selecting words. For example, Danielle is talking to a child who found a book said "I have been looking for this my whole life!" Danielle says "I think you are exaggerating." The child says "Really?" The educator says "Do you know what that means? Exaggerating? It means, say you guys are talking so much and I say I have a headache the size of a truck (gestures big with her hands). Could my head be the size of a truck?" The child says "No." The educator says "No, that's an exaggeration. I make it sound a lot bigger than it really is" When the researcher stopped the video and asked her about her thought process during this interaction, she did not report thinking of provision of that definition-rather she discussed making a connection to the child's life and giving the child a word to describe something the child often does (exaggerate). In another example, Deborah was observed defining the word "thorough" for a child during breakfast, saying the following to a child putting cream cheese on a bagel: "Gabriella, you are being very thorough. Thorough means that you are doing a good job covering the whole thing." In her reported reasoning, she identified a variety of purposes for teaching about words such as connecting back to previously taught words and stated, "I don't feel like I need to define. Like, they might have a grasp or I might just remind them." 


\section{DISCUSSION}

Educators in our study were reasoning about vocabulary instruction in complex ways, considering both what words to select as well as instructional strategies for teaching about words. Importantly, by using an innovative approach to studying-teaching, we were able to see that teachers used multiple types of knowledge to inform their support for vocabulary. These included knowledge about the curricular history, knowledge about individual children, knowledge about children more generally, and knowledge of instructional strategies. These types of knowledge have been discussed in the extant literature (e.g., Shulman, 1987); however, not all of them are accounted for in traditional measures of early childhood educator knowledge. Furthermore, our work highlights that educators were considering a variety of instructional strategies for teaching often not accounted for in observational measures. Thus, this work is critical in providing deeper insight early childhood educators' practice and has important implications for future research in understanding a critical early childhood practice with long-term impacts for reading outcomes. Next, we highlight our findings about knowledge use related to context, discuss educators' knowledge of instructional strategies, and then conclude with implications for future research.

\subsection{The centrality of the context}

Our findings suggest that the early childhood educators in our sample were reasoning about how to support vocabulary development in complex ways. They had various purposes for selecting words to teach children-however, having children acquire definitions of vocabulary words was rarely mentioned as a purpose. Rather, they were thinking carefully about their particular educational context and tailoring their support for vocabulary to their instructional history and children.

\subsubsection{Instructional history}

Educators were engaging in monitoring children's knowledge of previously taught words, by both reviewing and informally assessing children's knowledge of those words. It appeared that few, if any, of the educators gleaned those previously taught words from a formal curriculum or were prompted to review or assess those words from a educator's 
manual that was contextual-no educators in our sample referenced these outside sources when reporting their thought processes. Rather, it appears that they were holding the contextually specific information about words they had taught previously in various child-led interactions and were intentionally returning to those words to review and assess. Here, educators were using their deep knowledge of the language experiences that the children have had in their setting to inform their practice. They were using knowledge of their context and the instructional history therein to engage in documented practices for supporting vocabulary such as providing multiple exposures to a word (e.g., B.A. Wasik et al., 2016) and that assessing children's word knowledge (Graves, 2016).

\subsubsection{Children's needs}

Educators also reported thinking deeply about the children with whom they were working when making decisions about how to support their vocabulary learning. They reported calibrating the support they were providing for children based on key characteristics of the children in front of them-taking into account the words that may be unknown to the children, various characteristics of each learner that might affect word learning, and the different levels of vocabulary knowledge present in their population. In other words, their support for vocabulary was heavily informed by the children in their setting - a practice that is widely supported in the field of early childhood education (e.g., National Association for the Education of Young Children, 2009).

\subsubsection{General pedagogical practices}

Educators often reported situating their support for vocabulary within the activities, interests, and discussions that children had chosen, providing support that was semantically contingent in the context of joint attentional episodes. An extensive body of empirical research indicates that such exchanges are powerfully linked to vocabulary learning (e.g., Hassinger-Das, Toub, Hirsh-Pasek, \& Golinkoff, 2017; Hirsh-Pasek et al., 2015; Tomasello \& Farrar, 1986) and such practices are widely supported in the field of early childhood education (Bowman, Donovan, \& Burns, 2001; National Association for the Education of Young Children, 2009). 


\subsubsection{Synthesizing contextually based knowledge}

Findings suggest that the support for vocabulary development that early childhood educators were providing for children was principally informed by their unique educational context-by the pedagogical history of their setting, the language-related characteristics of their children, and the immediate language, interests, and activities of the children. As outlined in previous paragraphs, each of these practices is supported by both the field of early childhood education writ large and a solid body of research. Importantly, no educator explicitly referenced research or formal knowledge of these practices, similar to findings in prior work (Piasta et al., 2017) - it is unclear how or where they acquired this knowledge. However, it is reasonable to assume that educators were drawing from a substantial body of knowledge as they engaged in support for vocabulary-a knowledge base perhaps more substantial than has been previously been captured (Cash et al., 2015; Piasta et al., 2017). By asking educators to explicate their reasoning in the moment of instruction, we were able to observe numerous examples of how educators were enacting research-based strategies in contextually driven ways, illustrating how they were using their knowledge to inform inthe-moment practice.

\subsection{Going Beyond Defining}

Research has indicated that providing children with explicit definitions of vocabulary words is important to their word learning (e.g., Beck \& McKeown, 2007; Brett et al., 1996; Elley, 1989; Penno et al., 2002; Pressley et al., 2007; Silverman \& Crandell, 2010). Perhaps partially because of this research base, observational measures of support for vocabulary in preschools have centered on this practice and researchers using these measures have found a dearth of support for vocabulary learning (e.g., Landry et al., 2011; Pelatti et al., 2014; Wright \& Neuman, 2014).

\subsubsection{Limited focus on defining}

From one perspective, our findings would appear to add to the finding outlined in the previous paragraph-educators in our study rarely reported thinking about defining as a strategy to support word learning. On the other hand, our findings suggest that educators were reasoning about supporting vocabulary using several other research-based strategies for vocabulary learning that extend beyond defining, including 
labelling (Pan et al., 2005), modelling through use of unknown vocabulary (J. Huttenlocher, Vasilyeva, Cymerman, \& Levine, 2002), asking children to produce the phonological representation of the word (Beck \& McKeown, 2007; Biemiller \& Boote, 2006; Rosenthal \& Ehri, 2008; M. Senechal, 1997; M. Senechal et al., 1995), and providing information about word meanings (Beck \& McKeown, 2007; Biemiller \& Boote, 2006; M. Senechal, 1997; M. Senechal et al., 1995; Rosenthal \& Ehri, 2008). These findings suggest that early childhood educators may possess ample implicit or explicit knowledge about effective strategies for supporting vocabulary learning that go beyond the knowledge captured by our current measures. Further, they are reasoning about their strategies for supporting vocabulary in a highly context-specific manner, considering their goals for reviewing and assessing previously learned vocabulary, meeting children's needs, and contingent responsivity when making decisions about how to support learning.

It should be noted that although educators rarely discussed defining words for children as a goal or an instructional strategy, as reported in our results, we anecdotally observed some examples of educators defining words for children in the first-order data. In other words, there were times when educators were defining words for children, but this was not their focus in thinking about in-the-moment support for children's word learning. Instead, they either focused on contextually specific knowledge or other instructional strategies beyond defining, often using the former to inform the latter.

\subsection{Implications for research}

Overall, our findings suggest that there is a more complex and nuanced relationship between the knowledge that educators hold and what they do with that knowledge than has been previously understood. This finding has implications for educational research investigating early childhood educators' knowledge about how to support language development. Existing measures of educators' have been primarily of the "paper and pencil" variety, focusing on content and pedagogical content knowledge (Shulman, 1987). Such measures can be extensively piloted and established as valid and reliable measures of educator knowledge. In addition, they are easily administered to a large sample of educators, which allows researchers to generalize their findings to broad swaths

of educators. However, these measures are largely divorced from the 
unique classroom contexts of educators. They are not able to capture how educators synthesize their static knowledge about how to support vocabulary with their deep knowledge of the children in front of them and their history of interactions with those children to enact context-informed practice. We suggest that investigations into educators' knowledge about supporting language development using paper-and-pencil measures be supplemented by SRIs, or similar procedures that connect educators' internal thought process undergirding instruction. By adding SRIs or SRI-like methods to a suite of data collection methods, combined results will likely provide a more complex and nuanced illustration of the links between knowledge that educators hold and what they do with that knowledge. Others have also asserted a greater need for this type of work in studying-teaching (e.g., Kennedy, 2016), and we believe our findings support this assertion.

We posit that research that is primarily observing educator-child interactions in early childhood classrooms for instances of defining may not be capturing the full extent of how early childhood educators are conceptualizing and enacting support for children's vocabulary learning. The field could benefit from developing valid and reliable observational measures that document instructional strategies beyond provision of definitions.

We also believe that our research also has implications research into educators' enacted practice around support for vocabulary development. Our findings suggest that coupling expanded observational measures with measures of educators' pedagogical reasoning could be beneficial. First, this approach could illuminate the ways that educators' unique contexts inform their instructional decisions. Second, this may be particularly important given our finding that anecdotally observed instances of defining words were often not the focus of educators' pedagogical reasoning. Educators may be operationalizing vocabulary differently than researchers-possibly due to having differing priorities than researchers (Munby, 1982; Schachter, 2017) and may be using different language/terminology than researchers to describe similar language practices (Dwyer \& Harbaugh, 2018). Adding measures of educators' in-the-moment thinking to expanded observational protocols could inform our understanding of how educators' operationalize and conceptualize their in-the-moment practice, which could help bridge the gap between measures of knowledge and measures of practice. 


\subsection{Implications for professional development}

Our findings also have important implications for preservice and in-service professional development for early childhood educators. First, given the variety of strategies that early childhood educators reported using, professional development efforts for early childhood educators should recognize that at least some educators have knowledge and the ability to discuss using a range of instructional strategies to support vocabulary. Following adult learning theory (Knowles, 1970), professional development efforts should meet educators where they are in their current knowledge about effective practice and support them to improve in ways that build from existing expertise. Second, given the ways that educators in our sample used context-specific information to drive their varied supports for vocabulary development, it seems critically important that professional development include ample opportunities for educators to practice applying research-based strategies for supporting vocabulary to their educational context. Indeed, although there is evidence suggesting that professional development typically focuses on providing content knowledge (Cox, Hollingsworth, \& Buysse, 2015), our findings these data coupled with along with others' recommendations for high quality professional development (e.g., Desimone, 2009; Yoon, Duncan, Lee, Scarloss, \& Shapley, 2007) suggest that helping educators integrate their knowledge into their practice is critical (Piasta et al., 2017). Professional development efforts that have been less successful may need to do a better job of embedding the use of new knowledge in educators' immediate contexts, possibly through incorporating video analysis of practice and/or coaching.

\subsection{Limitations}

This study has four important limitations. First, because we had a small sample and the data produced from the SRIs were so context specific, we are not able to generalize our findings to a larger sample of early childhood educators. Additional research using SRIs on a larger sample might allow researchers to uncover general patterns of knowledge in use in different types of contexts. Second, we did not investigate how educators' decision making during support for vocabulary development impacts children's vocabulary learning. More research is necessary to study the 
nature of this relationship. Third, it is important to acknowledge the potential role of the researcher in shaping the type of instruction and pedagogical reasoning that was observed. Specifically, the presence of the researcher in the classroom may have shifted teachers' practice. Finally, as the study was focused on language instruction and only included a researcher-selected clip of small-group interactions from the entire observation, this may have also biased the types of data that were collected. More work using SRIs to study pedagogical reasoning about teaching words is needed.

\section{CONCLUSION}

Previous research investigating both the knowledge of early childhood educators and the support for vocabulary development present in early childhood settings has indicated that both educator knowledge and enacted practice are less than optimal for supporting children's long-term reading related outcomes (e.g., Piasta et al., 2017; Cash et al., 2015; Landry et al., 2011; Pelatti et al., 2014; Wright \& Neuman, 2014)and that the relationship between the two is unclear (e.g., Carlisle et al., 2009; Hindman \& Wasik, 2011; Pianta et al., 2014; Schachter et al., 2016; Spear et al., 2018). Our findings suggest that to develop a richer understanding of the relationship between knowledge and practice, it is important to uncover how early childhood educators are using the knowledge they hold in their moment-to-moment decision making. Indeed, results indicate that the early childhood educators in this study were (a) reasoning in complex, varied, and highly context-specific ways about their goals and strategies for supporting vocabulary learning and (b) incorporating research-based goals and strategies for supporting vocabulary learning. These findings have implications for future research investigating the relationship between knowledge and practice, as well as for research around and implementation of effective preservice and in-service professional development for early childhood educators. 


\section{REFERENCES}

Beck, I. L., \& McKeown, M. G. (2007). Increasing young low-income children's oral vocabulary repertoires through rich and focused instruction. The Elementary School Journal, 107, 251-271. https://doi.org/10.1086/511706

Biemiller, A., \& Boote, C. (2006). An effective method for building meaning vocabulary in primary grades. Journal of Educational Psychology, 98, 44-62. https://doi.org/10.1037/0022-0663.98.1.44

Bowman, B. T., Donovan, M. S., \& Burns, M. S. (2001). Eager to learn: Educating our preschoolers. Washington, DC: National Academy Press.

Brett, A., Rothlein, L., \& Hurley, M. (1996). Vocabulary acquisition from listening to stories and explanations of target words. The Elementary School Journal, 96(4), 415-422. https://doi.org/10.1086/461836

Cabell, S. Q., Justice, L. M., McGinty, A. S., DeCoster, J., \& Forston, L. D. (2015). Teacher-child conversations in preschool classrooms: Contributions to children's vocabulary development. Early Childhood Research Quarterly, 30, 80-92. https:// doi.org/10.1016/j.ecresq.2014.09.004

Carlisle, J. F., Correnti, R., Phelps, G., \& Zeng, J. (2009). Exploration of the contribution of teachers' knowledge about reading to their students' improvement in reading. Reading and Writing, 22, 457-486. https://doi.org/10.1007/s11145-009-9165-y

Cash, A. H., Cabell, S. Q., Hamre, B. K., DeCoster, J., \& Pianta, R. C. (2015). Relating prekindergarten teacher beliefs and knowledge to children's language and literacy development. Teaching and Teacher Education, 48, 97-105. https://doi. org/10.1016/j.tate.2015.02.003

Cherrington, S., \& Loveridge, J. (2014). Using video to promote early childhood teachers' thinking and reflection. Teaching and Teacher Education, 41, 42-51. https://doi.org/10.1016/j.tate.2014.03.004

Clark, C., \& Yinger, R. (1977). Research on teacher thinking. Curriculum Inquiry, 7, 279-304. https://doi.org/10.1080/03626784.1977.11076224

Cohen, D. K., Raudenbush, S. W., \& Ball, D. L. (2003). Resources, instruction, and research. Educational Evaluation and Policy Analysis, 25, 119-142. https://doi. org/10.3102/01623737025002119

Collins, M. F. (2010). ELL preschoolers' English vocabulary acquisition from storybook reading. Early Childhood Research Quarterly, 25(1), 84-97.

Corbin, J., Strauss, A., \& Strauss, A. L. (2014). Basics of qualitative research. Thousand Oaks, CA: Sage.

Cox, M. E., Hollingsworth, H., \& Buysse, V. (2015). Exploring the professional development landscape: Summary from four states. Early Childhood Research Quarterly, 32, 116-126. https://doi.org/10.1016/j.ecresq.2015.03.002

Coyne, M. D., McCoach, D. B., Loftus, S., Zipoli, R., Jr., \& Kapp, S. (2009). Direct vocabulary instruction in kindergarten: Teaching for breadth versus depth. The Elementary School Journal, 110(1), 1-18.

Creswell, J. W. (2007). Five qualitative approaches to inquiry. Qualitative inquiry and research design: Choosing among five approaches. Thousand Oaks, CA: SAGE Publications. 
Creswell, J. W., \& Creswell, J. D. (2018). Research design: Qualitative, quantitative, and mixed method approaches (5th ed.). Thousand Oaks, CA: Sage Publications.

Cunningham, A. E., \& Stanovich, K. E. (1997). Early reading acquisition and its relation to reading experience and ability 10 years later. Developmental Psychology, 33(6), 934-945. https://doi.org/10.1037/0012-1649.33.6.934

Desimone, L. M. (2009). Improving impact studies of teachers' professional development: Toward better conceptualizations and measures. Educational Researcher, 38, 181-199. https://doi.org/10.3102/0013189x08331140

Dwyer, J., \& Harbaugh, A. G. (2018). Where and when is support for vocabulary development occurring in preschool classrooms? Journal of Early Childhood Literacy, 1-44.

Elley, W. B. (1989). Vocabulary acquisition from listening to stories. Reading Research Quarterly, 24, 174-187. https://doi.org/10.2307/747863

Fernald, A., Marchman, V. A., \& Weisleder, A. (2013). SES differences in language processing skill and vocabulary are evident at 18 months. Developmental Science, 16(2), 234-248. https://doi.org/10.1111/desc.12019

Gonzalez, J. E., Pollard-Durodola, S., Simmons, D. C., Taylor, A. B., Davis, M. J., Kim, M., \& Simmons, L. (2010). Developing low-income preschoolers' social studies and science vocabulary knowledge through content-focused shared book reading. Journal of Research on Educational Effectiveness, 4(1), 25-52. https://doi.org/10.1 $\underline{080 / 19345747.2010 .487927}$

Graves, M. F. (2016). The vocabulary book: Learning and instruction (2nd ed.). New York, NY: Teachers College Press.

Grossman, P. L. (1990). The making of a teacher: Teacher knowledge and teacher education. New York, NY: Teachers College Press, Teachers College Columbia University.

Hadley, E. B., Dickinson, D. K., Hirsh-Pasek, K., Golinkoff, R. M., \& Nesbitt, K. T. (2016). Examining the acquisition of vocabulary knowledge depth among preschool students. Reading Research Quarterly, 51(2), 181-198. https://doi.org/10.1002/ $\underline{\operatorname{rrq} .130}$

Hassinger-Das, B., Toub, T. S., Hirsh-Pasek, K., \& Golinkoff, R. M. (2017). A matter of principle: Applying language science to the classroom and beyond. Translational Issues in Psychological Science, 3(1), 5-18. https://doi.org/10.1037/tps0000085

Hindman, A. H., \& Wasik, B. A. (2011). Measuring teachers' knowledge about early language and literacy: Practical implications and considerations. NHSA Dialog, 14(4), 351-356. https://doi.org/10.1080/15240754.2011.618647

Hirsh-Pasek, K., Adamson, L. B., Bakeman, R., Owen, M. T., Golinkoff, R. M., Pace, A., ... Suma, K. (2015). The contribution of early communication quality to low-income children's language success. Psychological Science, 26(7), 1071-1083. https://doi. org/10.1177/0956797615581493

Hoff, E. (2006). How social contexts support and shape language development. Developmental Review, 26, 55-88. https://doi.org/10.1016/i.dr.2005.11.002

Hoff, E. (2013). Interpreting the early language trajectories of children from lowSES and language minority homes: Implications for closing achievement gaps. Developmental Psychology, 49, 4-14. https://doi.org/10.1037/a0027238 
Huttenlocher, J., Vasilyeva, M., Cymerman, E., \& Levine, S. (2002). Language input and child syntax. Cognitive Psychology, 45 (3), 337-374. https://doi.org/10.1016/ S0010-0285(02)00500-5

Huttenlocher, J., Waterfall, H., Vasilyeva, M., Vevea, J., \& Hedges, L. V. (2010). Sources of variability in children's language growth. Cognitive Psychology, 61, 343-365. https://doi.org/10.1016/j.cogpsych.2010.08.002

Kane, T. J., \& Staiger, D. O. (2012). Gathering feedback for teaching: Combining highquality observations with student surveys and achievement gains. Research Paper. MET Project. Bill \& Melinda Gates Foundation.

Kennedy, M. (2016). Parsing the practice of teaching. Journal of Teacher Education, 67, 6-17. https://doi.org/10.1177/0022487115614617

Knowles, M. S. (1970). The modern practice of adult education (Vol. 41). New York: New York Association Press.

Lampert, M. (2001). Teaching problems and the problems of teaching. New Haven, CT: Yale University Press.

Landry, S. H., Swank, P., Anthony, J., \& Assel, M. (2011). An experimental study evaluating professional development activities within a state funded prekindergarten program. Reading and Writing, 24, 971-1010. https://doi. org/10.1007/s11145-010-9243-1

Lyle, J. (2003). Stimulated recall: A report on its use in naturalistic research. British Educational Research Journal, 29(6), 861-878. https://doi.org/10.1080/0141192 $\underline{032000137349}$

Markussen-Brown, J., Juhl, C. B., Piasta, S. B., Bleses, D., Højen, A., \& Justice, L. M. (2017). The effects of language- and literacy-focused professional development on early educators and children: A best-evidence meta-analysis. Early Childhood Research Quarterly, 38, 97-115. https://doi.org/10.1016/j.ecresq.2016.07.002

Marton, F. (1981). Phenomenography-Describing conceptions of the world around us. Instructional Science, 10, 177-200. https://doi.org/10.1007/BF00132516

Marulis, L. M., \& Neuman, S. B. (2010). The effects of vocabulary intervention on young children's word learning: A meta-analysis. Review of Educational Research, 80, 300-335. https://doi.org/10.3102/0034654310377087

Mol, S. E., Bus, A. G., \& De Jong, M. T. (2009). Interactive book reading in early education: A tool to stimulate print knowledge as well as oral language. Review of Educational Research, 79(2), 979-1007. https://doi. org/10.3102/0034654309332561

Munby, H. (1982). The place of teachers' beliefs in research on teacher thinking and decision making, and an alternative methodology. [journal article]. Instructional Science, 11, 201-225. https://doi.org/10.1007/bf00414280

National Association for the Education of Young Children (2009). NAEYC position statement: Developmentally appropriate practice in early childhood programs serving children from birth through age 8. Retrieved from http://208.118.177.216/about/positions/pdf/PSDAP.pdf

National Early Literacy Panel (2008). Developing early literacy. Washington, D. C: National Institute for Literacy. 
National Reading Panel (2000). Teaching children to read: An evidence-based assessment of the scientific literature on reading and its implications for reading instruction. Report for the US Department of Education. Washington, DC: US Department of Education.

Neuman, S. B., \& Cunningham, L. (2009). The impact of professional development and coaching on early language and literacy instructional practices. American Educational Research Journal, 46, 532-566. https://doi. org/10.3102/0002831208328088

O'Leary, P. M., Cockburn, M. K., Powell, D. R., \& Diamond, K. E. (2010). Head Start teachers' views of phonological awareness and vocabulary knowledge instruction. Early Childhood Education Journal, 38, 187-195. https://doi.org/10.1007/ s10643-010-0394-0

Pan, B. A., Rowe, M. L., Singer, J. D., \& Snow, C. E. (2005). Maternal correlates of growth in toddler vocabulary production in low income families. Child Development, 76, 763-782.

Pelatti, C. Y., Piasta, S. B., Justice, L. M., \& O'Connell, A. A. (2014). Language- and literacy-learning opportunities in early childhood classrooms: Children's typical experiences and within-classroom variability. Early Childhood Research Quarterly, 29, 445-456. https://doi.org/10.1016/j.ecresq.2014.05.004

Penno, J. F., Wilkinson, A. G., \& Moore, D. W. (2002). Vocabulary acquisition from teacher explanation and repeated listening to stories: Do they overcome the Matthew effect? Journal of Educational Psychology, 94, 23-33. https://doi. org/10.1037/0022-0663.94.1.23

Pianta, R. C., Burchinal, M., Jamil, F. M., Sabol, T., Grimm, K., Hamre, B. K., \& Howes, C. (2014). A cross-lag analysis of longitudinal associations between preschool teachers' instructional support identification skills and observed behavior. Early Childhood Research Quarterly, 29, 144-154. https://doi.org/10.1016/j. ecresq.2013.11.006

Piasta, S. B., Connor, C. M., Fishman, B., \& Morrison, F. J. (2009). Teachers' knowledge of literacy, classroom practices, and student reading growth. Scientific Studies of Reading, 13, 224-228. https://doi.org/10.1080/10888430902851364

Piasta, S. B., Justice, L. M., O'Connell, A. A., Mauck, S. A., Weber-Mayrer, M., Schachter, R. E., ... Spear, C. F. (2017). Effectiveness of large-scale, state-sponsored language and literacy professional development on early childhood educator outcomes. Journal of Research on Educational Effectiveness, 10(2), 354-378. https://doi.org/ $\underline{10.1080 / 19345747.2016 .1270378}$

Pressley, M., Disney, L., \& Anderson, K. (2007). Landmark vocabulary instructional research and the vocabulary instructional research that makes sense now. In R. K. Wagner, A. E. Muse, \& K. R. Tannenbaum (Eds.), Vocabulary acquisition: Implications for reading comprehension (pp. 205-232). New York, NY: Guilford Press.

Quinn, J. M., Wagner, R. K., Petscher, Y., \& Lopez, D. (2015). Developmental relations between vocabulary knowledge and reading comprehension: A latent change score modeling study. Child Development, 86(1), 159-175. https://doi. org/10.1111/cdev.12292 
Rosenthal, J., \& Ehri, L. C. (2008). The mnemonic value of orthography for vocabulary learning. Journal of Educational Psychology, 100(1), 175-191. https://doi. org/10.1037/0022-0663.100.1.175

Schachter, R. E. (2017). Early childhood teachers' pedagogical reasoning about how children learn during language and literacy instruction. International Journal of Early Childhood, 49, 95-111. https://doi.org/10.1007/s13158-017-0179-3

Schachter, R. E., \& Freeman, D. (2015). Using stimulated recall to study teachers and teaching: A brief introduction to the research methodology. In P. Oliveira Lucas, \& R. Lourenco Rodrigues (Eds.), Temas e Rumos nas Pesquisas em Linguistica (Aplicada): Questos empiricas, eticas e praticas, Vol. 1 (pp. 223-243). Brazil: Pontas.

Schachter, R. E., Spear, C. F., Piasta, S. B., Justice, L. M., \& Logan, J. A. R. (2016). Early childhood educators' knowledge, beliefs, experiences, and children's languageand literacy-learning opportunities: What is the connection?. Early Childhood Research Quarterly, 36, 281-294.

Senechal, M. (1997). The differential effect of storybook reading on preschoolers' acquisition of expressive and receptive vocabulary. Child Language, 24, 123-138. https://doi.org/10.1017/S0305000996003005

Senechal, M., Ouelette, G., \& Rodney, D. (2006). The misunderstood giant: On the predictive role of early vocabulary to future reading. In D. K. Dickinson, \& S. B. Neuman (Eds.), Handbook of early literacy research (Vol. 2) (pp. 173-182). New York, NY: Guilford Press.

Senechal, M., Thomas, E., \& Monker, J. A. (1995). Individual differences in 4-yearold children's acquisition of vocabulary during storybook reading. Journal of Educational Psychology, 87, 218-229. https://doi.org/10.1037/0022$\underline{0663.87 .2 .218}$

Shavelson, R., \& Stern, P. (1981). Research on teachers' pedagogical thoughts, judgments, decisions, and behaviors. Review of Research in Education, 51, 455498. https://doi.org/10.3102/00346543051004455

Shulman, L. (1987). Knowledge and teaching: Foundations of the new reform. Harvard Educational Review, 57, 1-23. https://doi.org/10.17763/ haer.57.1.j463w79r56455411

Silverman, R., \& Crandell, J. D. (2010). Vocabulary practices in prekindergarten and kindergarten classrooms. Reading Research Quarterly, 45(3), 318-340. https:// doi.org/10.1598/RRQ.45.3.3

Snow, C. E., Burns, M., \& Griffin, P. (1998). Preventing reading difficulties in young children. Washington, D.C.: National Academies Press.

Spear, C. F., Piasta, S. B., Yeomans-Maldonado, G., Ottley, J. R., Justice, L. M., \& O'Connell, A. A. (2018). Early childhood general and special educators: An examination of similarities and differences in beliefs, knowledge, and practice. Journal of Teacher Education, 69, 263-277. https://doi. org/10.1177/0022487117751401

Stahl, S. A., \& Fairbanks, M. M. (1986). The effects of vocabulary instruction: A model-based meta-analysis. Review of Educational Research, 56(1), 72-110. 
Tomasello, M., \& Farrar, M. J. (1986). Joint attention and early language. Child Development, 57(6), 1454-1463. https://doi.org/10.1111/j.1467-8624.1986. tb00470.x

Wasik, B. A., Bond, M. A., \& Hindman, A. (2006). The effects of a language and literacy intervention on Head Start children and teachers. Journal of Educational Psychology, 98, 63-74. https://doi.org/10.1037/0022-0663.98.1.63

Wasik, B. A., \& Hindman, A. H. (2011). Improving vocabulary and pre-literacy skills of at-risk preschoolers through teacher professional development. Journal of Educational Psychology, 103(2), 455-469. https://doi.org/10.1037/a0023067

Wasik, B. A., Hindman, A. H., \& Snell, E. K. (2016). Book reading and vocabulary development: A systematic review. Early Childhood Research Quarterly, 37, 39-57. https://doi.org/10.1016/j.ecresq.2016.04.003

Weiland, C., \& Yoshikawa, H. (2013). Impacts of a prekindergarten program on children's mathematics, language, literacy, executive function, and emotional skills. Child Development, 84, 2112-2130. https://doi.org/10.1111/cdev.12099

Wright, T. S., \& Neuman, S. B. (2014). Paucity and disparity in kindergarten oral vocabulary instruction. Journal of Literacy Research, 46, 330-357. https://doi. org/10.1177/1086296x14551474

Yoon, K. S., Duncan, T., Lee, S. W.-Y., Scarloss, B., \& Shapley, K. (2007). Reviewing the evidence on how teacher professional development affects student achievement. Washington, D.C.: U.S. Department of Education, Institute of Education Sciences, Regional Educational Laboratory Southwest. 